\title{
Event review: How Interesting Archaeology Is! - Captivating and Leading-Edge Student Research
}

\author{
Atsushi Uemine \\ The Hakubi Center for Advanced Research / Institute for Research in Humanities, Kyoto University, Japan. \\ Email: uemine.atsushi.3z@kyoto-u.ac.jp
}

Kyoto City Archaeological Museum situated in Kansai region, the central part of Honshu Island, Japan, has held special exhibitions in collaboration with external organizations every year since 2011. From 2011 to 2013, several universities and even a high school have participated projects, and in 2014, the Kansai Archaeological Association for Students (KAAS) played an important role as partner, producing the exhibit “ここまでわか る！考古学—学生が魅せる最先端” (“How Interesting Archaeology Is! - Captivating and Leading-Edge Student Research”).

The Kansai Archaeological Association for Students, commonly known as 'Kangakukou' (the abbreviation of Kansai Gakusei Koukogaku Kenkyukai in Japanese), is a study group which consists of students and young researchers who are studying archaeology in various universities, research institutes, museums, and administrative organizations in the Kansai region. KAAS was established in 2003 by students of the time from several universities, including the author. Since then, KAAS members have had good opportunities to share research results, to develop research skills, and to communicate with each other regardless of their affiliation. Although students have limited knowledge of archaeology and little financial resources, they have unfettered thought, free from previous studies and much time to devote themselves to basic research. These advantages have promoted empirical research since the mid-20th century, and thus 'student archaeology' has been one of the notable characteristics of the academic world of archaeology in Japan.

The 2014 exhibition was held from 16 December 2014 to 25 January 2015. During preparation for the exhibition, KAAS members chose 7 research subjects, and as leaders of each subject young researchers continued to investigate and observe archaeological sites, features, and artifacts. The young researchers were assisted by approximately 50 students from 9 universities who participated in the project in order to train to become archaeologists and museum curators in the future (Figure 1). Not only students of archaeology and history but also students of design joined our project. Miyuki Nisii, an undergraduate student majoring in Illustration at the Faculty of Arts and Design, Osaka Seikei University, led the exhibition design of our project. Nisii and her classmates designed signboards, exhibition panels, a pictorial record book, mascot characters, and commemorative rubber stamps (Figure 2). She says that, "This is the first time for us to practice our design skills as work experience.

Published by the School of History, Classics and Archaeology, University of Edinburgh ISSN: 2055-0472. URL: http://journals.ed.ac.uk/lithicstudies/

This work is licensed under a Creative Commons Attribution 2.5 UK: Scotland License. 
It was hard to keep the deadlines of delivery and sometimes we were requested to improve the quality of the products, but this exhibition became a really good experience and we were able to learn many things." The 7 research subjects were as follows: zooarchaeology and sclerochronology of the dietary culture and the site formation process (led by Takashi Nayauchi and Satoshi Hatakeyama); experimental study of iron production (led by Kohei Yamamoto); Cristian artifacts in Kyoto (led by Masayoshi Shimizu); technological analysis of haniwa, ceramic funerary sculptures from within tumuli (led by Masahiro Harada); a dynamic approach to identifying the function of horse trappings (led by Katsuki Oe); the decorating method of Jomon pottery (led by Yusuke Seno); archaeological and chemical study of obsidian artifacts (led by the author). This research attracted over 1,800 visitors with the help of exhibition commentary by the students. In the obsidian section, “黑曜岩、600km の旅” ("Obsidian, 600 km Journeys"), Natsuko Matsuo and Ayaka Suzuki, undergraduate students of Nara University, introduced the following research results and explained about materials which they imaginatively displayed (Figure 3).

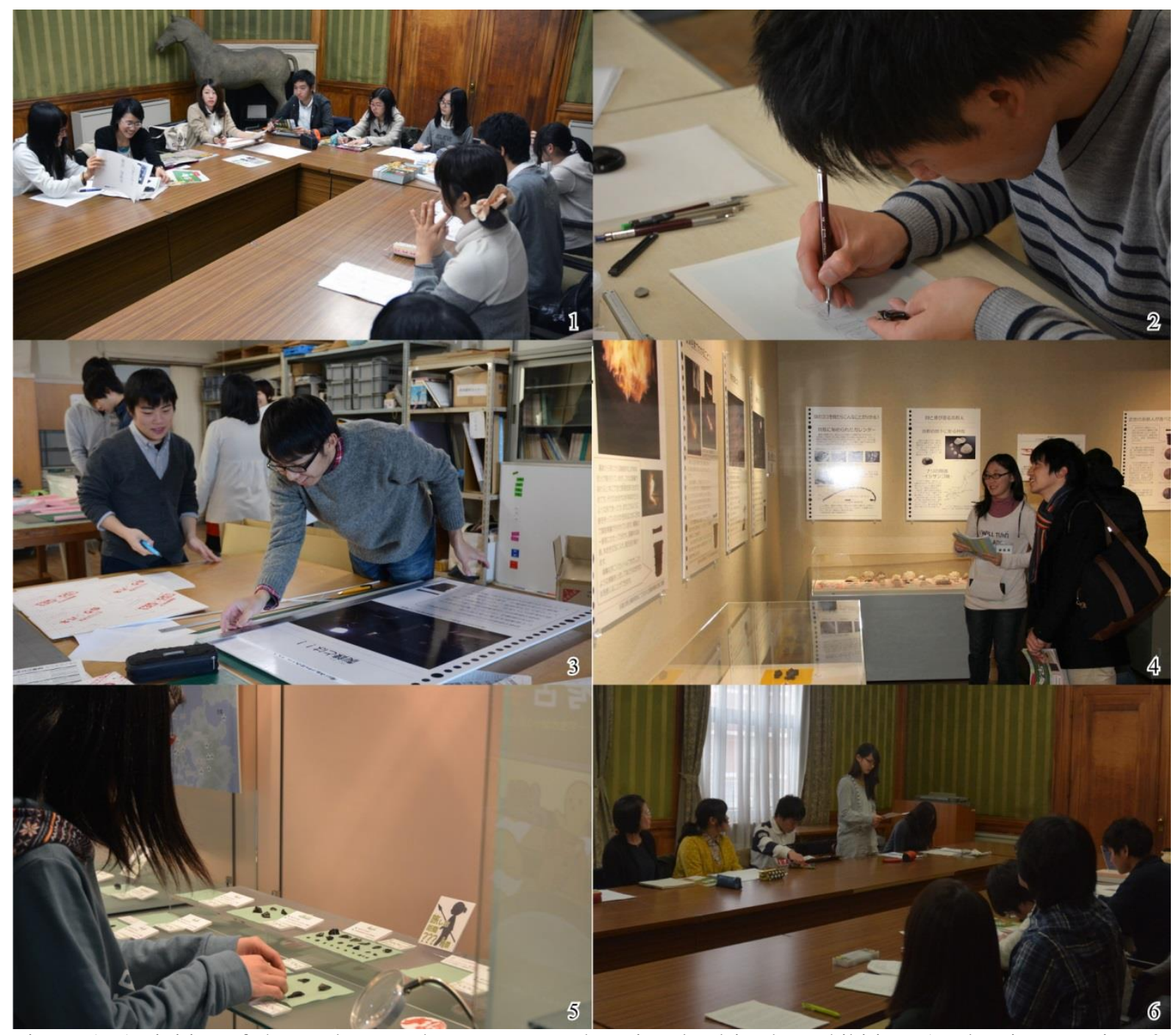

Figure 1. Activities of the students and young researchers involved in the exhibition. 1. Planning meeting. 2. Observing and making scale drawings of artifacts. 3. Preparation for the exhibition. 4. A gallery talk. 5. Fine adjustment of exhibits. 6 . Review meeting. 

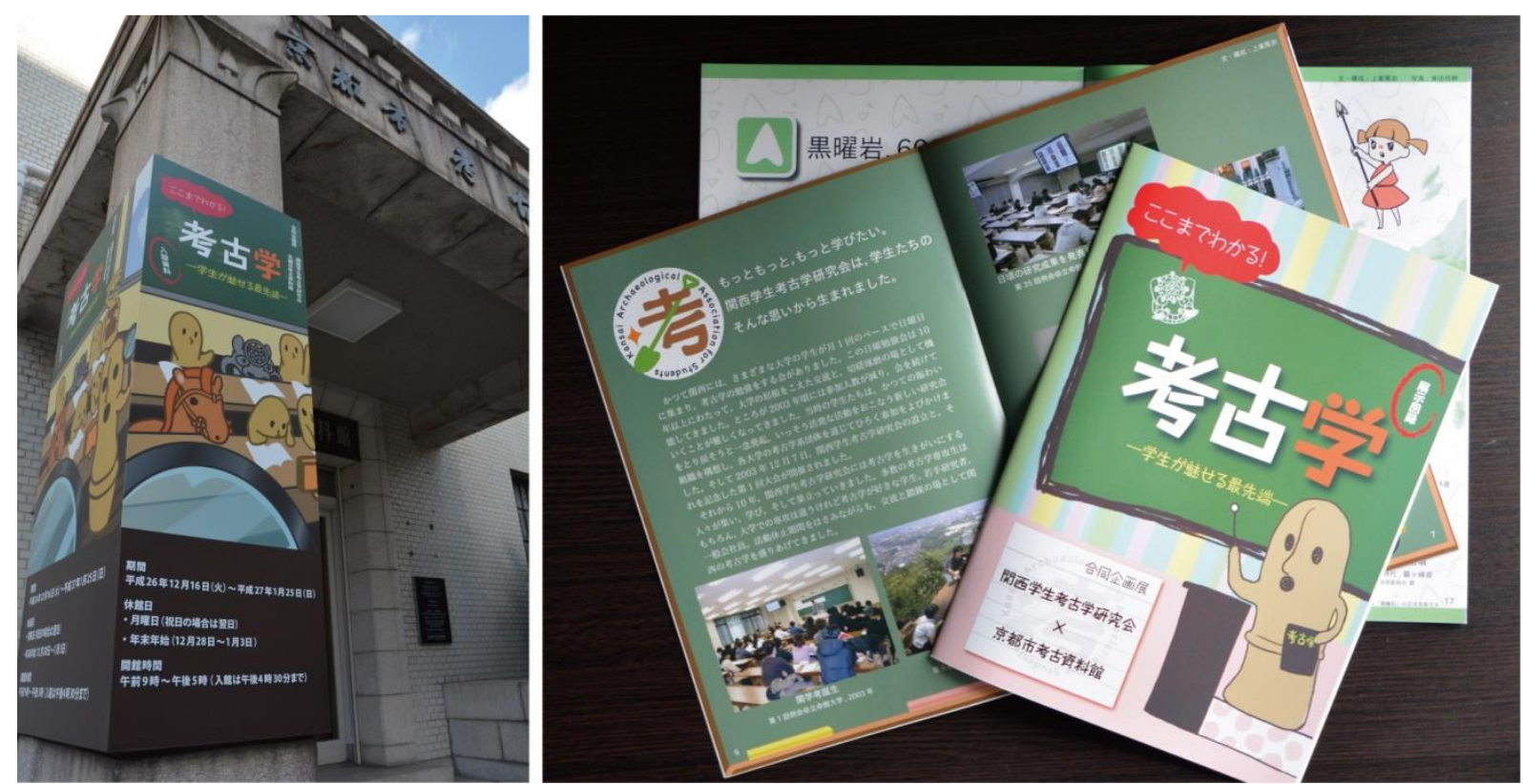

Figure 2. Signboard and pictorial record book designed by the students of Osaka-Seikei University.

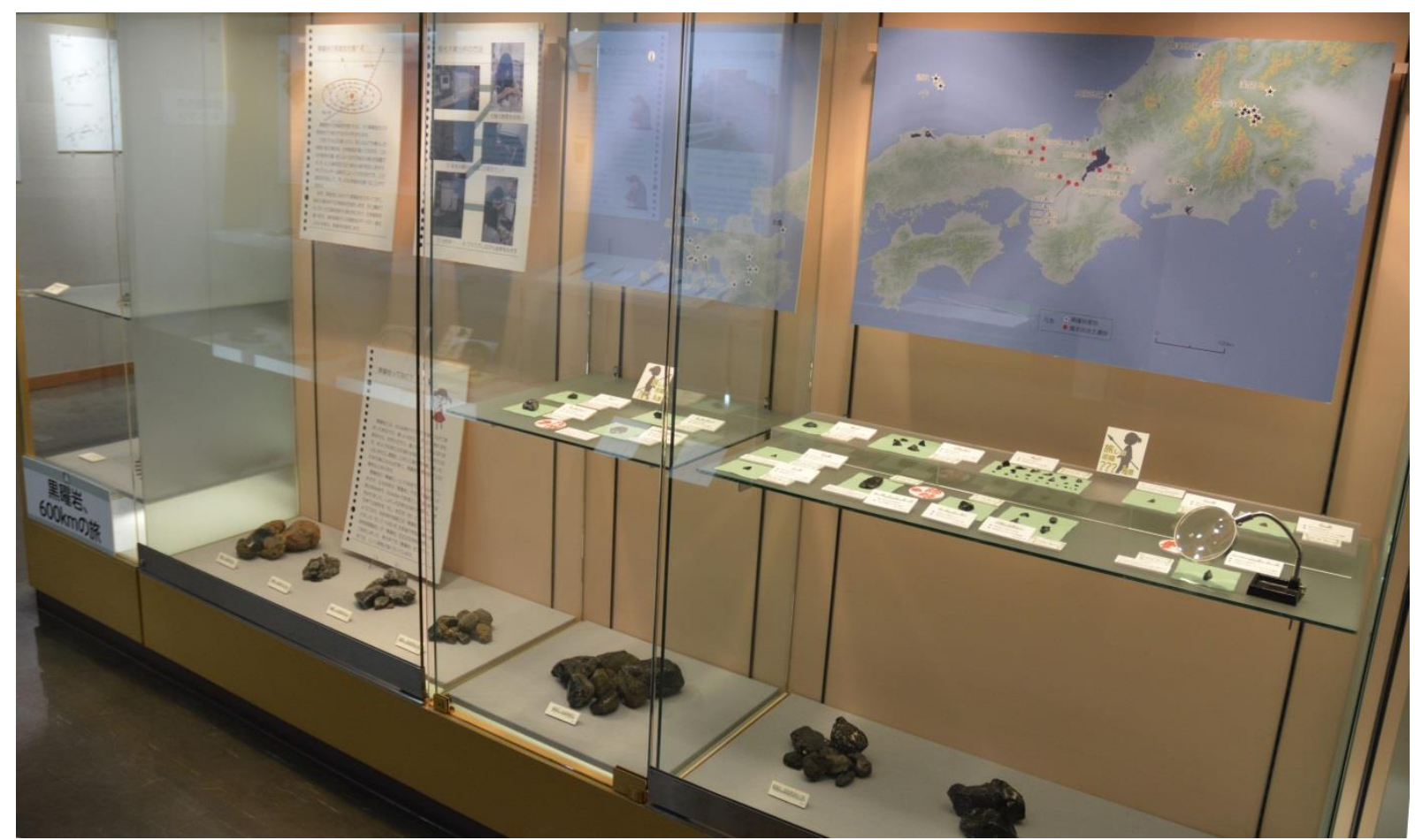

Figure 3. Obsidian exhibition section "Obsidian, 600 km Journeys".

Even considering only major sources, the Japanese archipelago has approximately 200 obsidian sources (Figure 4), a situation owing to the geological background as the part of circum-Pacific volcanic belt. Obsidian sourcing studies have become some of the most important research areas to demonstrate some form of ancient trade. Some researchers have tried to utilize INAA (Ninomiya et al. 1993) and ICP-AES (Miura et al. 2012) for sourcing, but the majority focus on minor elements detected by XRF. EDXRF in particular, is the most popular method in sourcing studies of obsidian artifacts because it is a non-destructive and inexpensive method for analysis. Owing to the progress of analytical instruments and provenance analysis methods, it has been possible to accumulate sourcing data for all lithic artifacts within an assemblage, including debris, in order to obtain quantitative information 
about the lithic raw material utilization within the assemblage as a whole. Nowadays, on the basis of research carried out by Meiji University, EDXRF analysis can distinguish 85 groups of obsidian source points (Sugihara 2011). Obsidian sources are concentrated in Hokkaido, the eastern area of Honshu, and Kyusyu, but Kansai region, the central area of Honshu, has not even one. Nevertheless, some obsidian artifacts unearthed from the archaeological sites of Kansai region with large number of andesite artifacts imply the existence of ancient interregional relationships.

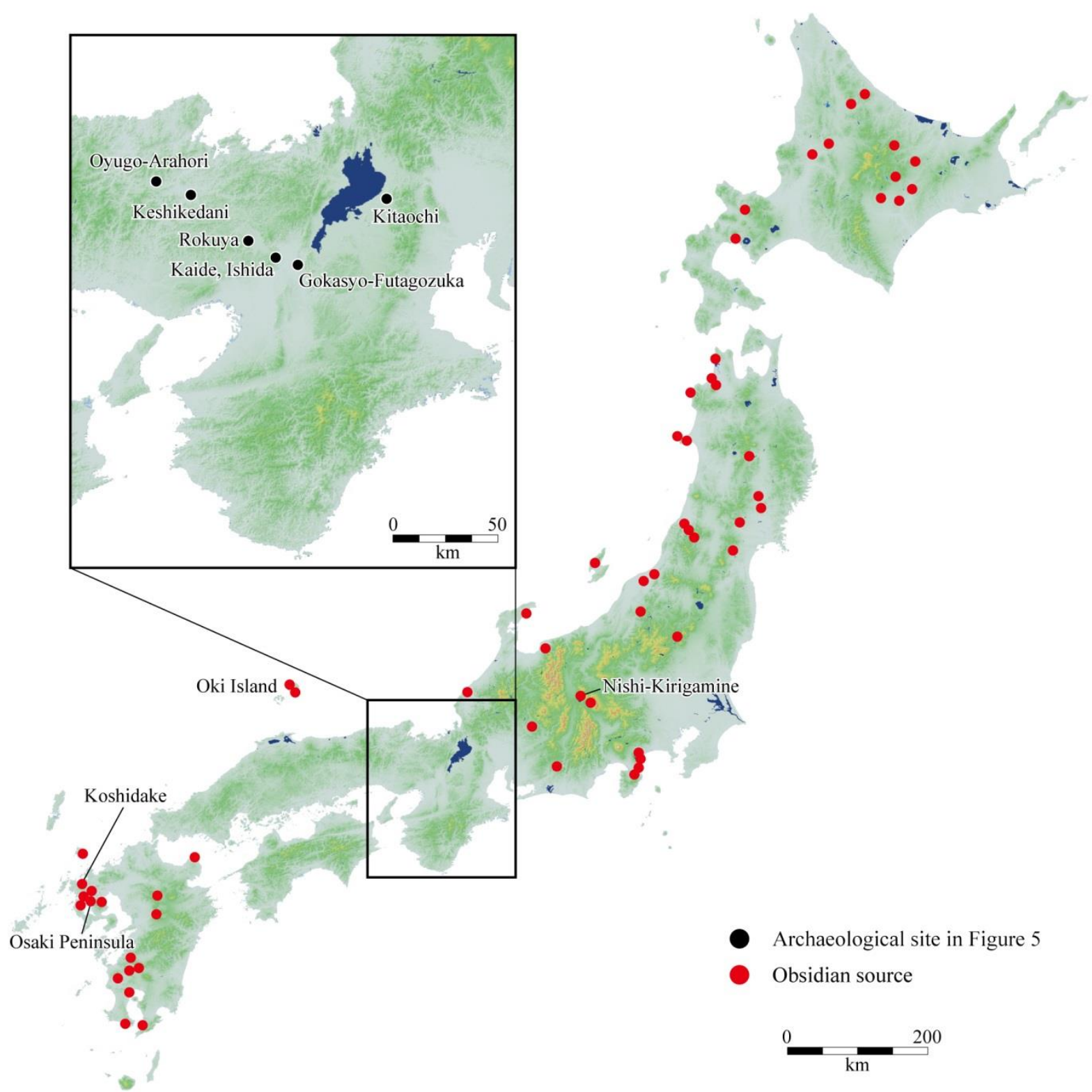

Figure 4. Obsidian source areas of Japanese Archipelago (after Sugihara 2011) and obsidian from archaeological sites discovered in Kansai region (made with Kashmir 3D).

To verify this, it is necessary to identify the petrological origin and archaeological details of these artifacts. 41 obsidian artifacts were selected and borrowed from their custodians and in cooperation with the Kyoto City Archaeological Museum, as a part of the exhibition project, they were observed archaeologically and subjected to provenance analysis by EDXRF. Taro Kannari, a researcher at the Center for Obsidian and Lithic Studies, Meiji University, was in charge of the sourcing study by EDXRF (JSX-3100s) and clarified that the 
obsidians were transported over long distances ranging from approximately 200 to $600 \mathrm{~km}$. The result prompted the author to try to determine their age by diverse methods. As is often the case with Neolithic archaeology, lithic artifacts are dated on the basis of the relative chronology of pottery which accompanied them. This time, the author cross-checked the age of the obsidian artifacts with the research on lithic typology and technology and with research on the temporal change in lithic raw material utilization patterns, as well as with the pottery chronology. Additionally, the edge sharpness and the degree of damage to flaking surfaces were observed very carefully. They could be considered as "transportation damage" and suggest where the obsidian artifacts were made.
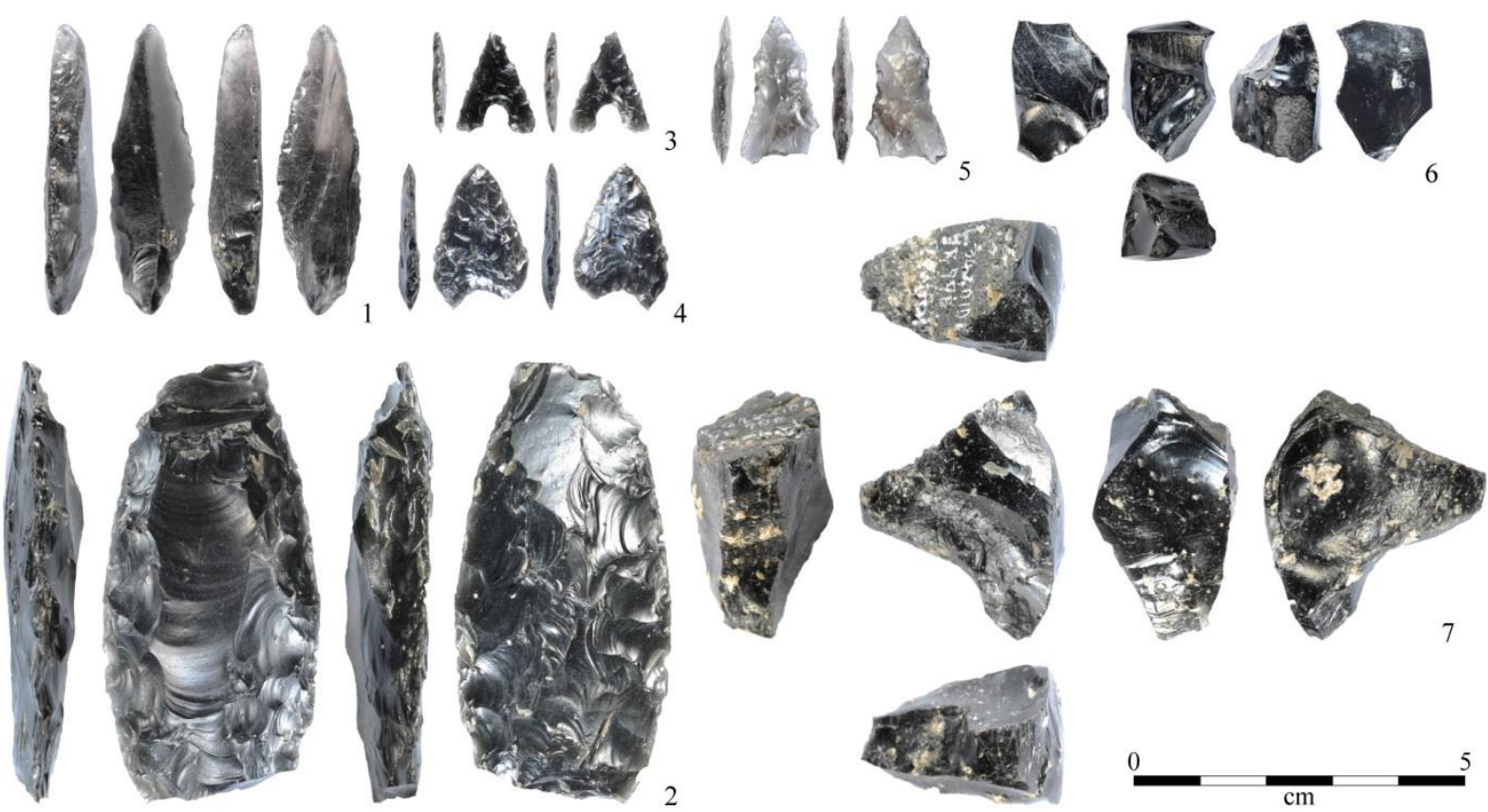

Figure 5. Obsidian artifacts unearthed in Kansai region, Japan (Photography by Masaki Shibata). 1. Backedblade from the Gokasyo-Futagozuka site, Upper Palaeolithic Period, Nishi-Kirigamine series obsidian (owned by Uji City Board of Education). 2. Point from the Rokuya site, possibly Incipient Jomon Period, Oki Island series obsidian (owned by Kameoka City Board of Education). 3. Arrowhead from the Oyugo-Arahori site, Early Jomon Period, Oki Island series obsidian (owned by Fukuchiyama City Board of Education). 4. Arrowhead from the Keshikedani site, Early Jomon Period, Oki Island series obsidian (owned by Fukuchiyama City Board of Education). 5. Arrowhead from the Kitaochi site, Final Jomon Period, Nishi-Kirigamine series obsidian (owned by Shiga Prefecture Board of Education). 6. Thermal fractured piece from the Ishida site, Final Jomon Period, Osaki Peninsula series obsidian (owned by Muko City Board of Education). 7. Thermal fractured piece from the Kaide site, Final Jomon Period, Koshidake series obsidian (owned by Muko City Board of Education).

In consequence, three patterns were identified in the relationship between the provenance of obsidian and the place of lithic production. In the 1st pattern, after making stone tools near the source areas, obsidian artifacts were transported over long distances. In the 2nd pattern, after procurement and transportation, lithic production was carried out far from the source areas. Obsidian artifacts classified into the 1st pattern have the same typological characteristics as those excavated at sites near the source areas, and have many damages like scratches on their surface. The backed blade of the Gokasho-futagozuka site which has technological features common in eastern Japan and much damage on the surface and ridge, could suggest an aspect of nomadic lifestyle during the Palaeolithic (Figure 5.1). In contrast, artifacts of the 2nd pattern, for instance, the arrowheads of the Oyugo-Arahori site, Keshikedani site and Kitaochi site, have a design common in the area where they were excavated and little damage on their surfaces (Figures 5.3, 5.4, 5.5). The 3rd pattern is, as it were, exceptional; debris produced during obsidian tool making was transported to Kansai 
region, a non-obsidian region far from source areas (Figures 5.6, 5.7). As a result of XRF analysis, all of the obsidian artifacts classified into this category were revealed to have been transported from Kyusyu Island and were dated to the middle of the Final Jomon Period, c. 3,300 cal. BP.

Why was debris transported? During this phase, the pottery types were uniformized throughout the whole of western Japan. Hence, the movement of obsidian from the Kyusyu region to the Kansai region can be interpreted as a reflection of the same cultural event. This phase corresponds to the start of the early stage of rice-paddy cultivation in the Japanese archipelago. Obsidian could be testimony to an encounter with people living in distant regions.

"Knowing something new and meeting someone new enrich our lives," says Takuya Asai, the representative of KAAS. Through the special exhibition, we the members of the KAAS exhibition project, fully enjoyed many encounters and learned numerous things from them. The Jomon people may also have learned new cultural elements by encountering distant people. Obsidians certainly know the fact.

\section{Acknowledgements}

I would like to show my greatest appreciation to Mr. Yasuhiro Takagi who provided helpful comments and suggestions.

\section{References}

Miura, M., Tateishi, T. \& Ninomiya, S. 2012, ICP 発光分光分析を用いた遺跡出土黒曜石 石器の原産地推定に関する基礎的研究. In: 日本文化財科学会第29 回大会研究発 表要旨集 (The 29th Annual Meeting of the Japan Society for Scientific Studies on Cultural Property Abstracts Volume) (Hirokazu Nagae, Ed.), The 29th Annual Meeting of the Japan Society for Scientific Studies on Cultural Property Executive Office, Kyoto: p. 242-243. (in Japanese) ("Basic research with ICP-AES on excavated obsidian tools for its presumable place of origin")

Ninomiya, S., Aboshi, M. \& Osawa, M. 1993, 男女倉遺跡群詳細分布調査における黒曜石 資料の原産地推定一機器中性子放射化分析による微量成分元素存在量からの検 討一. In: 黒耀石原産地遺跡分布調査報告書（和田峠・男女倉） (Survey Report of Wadatoge and Omekuradani Obsidian Source site of Nagano Prefecture) (Minoru Morishima and Koichi Moriyama, Ed.), Wada Village Board of Education, Nagano: p. 178-202. (in Japanese) ("Sourcing Obsidian Artifacts of Omekura sites from Minor Elements Abundance with INAA")

Sugihara, S. 2011, 蛍光 $X$ 線分析装置による黒曜石製遺物の原産地推定一基礎データ集 〈2〉 - . Cultural Properties Laboratory of Meiji University, Tokyo, 294 p. (in Japanese) ("Souring Obsidian Artifacts Using X-ray Fluorescence Analyzer - Data book (2)") 